\title{
Feeding the newborn: comparative problems in man and animals
}

\author{
By Elsie M. Widdowson, Department of Investigative Medicine, University of \\ Cambridge, Cambridge CB2 I $Q N$
}

The human problems that we will hear about later in this meeting concern feeding babies of unusual weights; first, babies that weigh too little at birth and secondly, babies that weigh too much after birth because they have been over-fed. Somewhat similar situations occur in animals, either in their natural circumstances, or as a result of experimental procedures. I shall describe examples of these in relation to the problems of feeding the human baby.

A low birth weight may be due simply to prematurity: the foetus has grown normally but it has been born too soon. On the other hand, it may be due to slow growth in the uterus so that the baby is small for its gestational age. Such a baby may be born prematurely or it may be born at full term. If it is born prematurely it has the double handicap of immaturity and small size for its gestational age.

As far as I know, no animal born after only $70 \%$ of its full gestation period has survived, yet human babies are now being reared when they have been born after only 28 weeks' gestation instead of 40 , and weighing only about I $\mathrm{kg}$, or less than $30 \%$ of the average weight at full term. The small size in itself presents difficulties, but the major problem about prematurity is immaturity. Although such extreme prematurity as this, with survival, does not occur in the animal kingdom, extreme immaturity does. Many of the rodents, mice, rats and rabbits, for example, have young that are immature and helpless at birth, with eyes and ears still closed, and the same applies to carnivores, dogs, cats, lions, tigers and foxes. All these species have a number of young at one time. The mother makes a nest for them before they are born, and warmth is essential for their survival. They depend upon the warmth of the mother's body and huddling with the rest of the litter to maintain a body temperature sufficiently high to enable their metabolic processes to proceed efficiently. They have short limbs and short tails which make for a small surface area, and this helps to prevent heat loss. These immature newborn animals also require a constant supply of food. The mouse and rat spend about $80 \%$ of their time suckling the newborn litters, and in cats and other carnivores the mother rarely leaves her young for the first few days, even to feed herself. The newborn rabbit, which has only one feed per $d$, is in effect being constantly fed because its large stomach acts as a reservoir; it empties slowly so that there is a continuous supply of nutrients being passed through the pylorus into the small intestine where they are digested and absorbed. This, and the generous supply of brown adipose tissue with which the newborn rabbit is endowed, enables it to survive in spite of the intermittent way in which it is fed, and the lack of maternal warmth and care. In the 
Table 1. Composition of the milk of some rodents and carnivores

\begin{tabular}{|c|c|c|c|c|c|}
\hline & $\begin{array}{l}\text { Protein } \\
\text { (g/1) }\end{array}$ & $\begin{array}{l}\text { Fat } \\
(g / 1)\end{array}$ & $\begin{array}{c}\text { Carbohydrate } \\
(\mathrm{g} / 1)\end{array}$ & $\begin{array}{l}\text { Calcium } \\
(\mathrm{mmol} / \mathrm{l})\end{array}$ & $\begin{array}{l}\text { Phosphorus } \\
\text { (mmol/1) }\end{array}$ \\
\hline \multicolumn{6}{|l|}{ Rodents } \\
\hline Rat & 90 & 90 & 30 & 95 & 81 \\
\hline Rabbit & 130 & I 50 & 20 & 125 & I Io \\
\hline \multicolumn{6}{|c|}{ Carnivores } \\
\hline Cat & IIO & I IO & 30 & - & - \\
\hline Dog & 80 & 90 & 40 & 70 & 78 \\
\hline Fox & 60 & 70 & 40 & - & $m$ \\
\hline
\end{tabular}

immature newborn of all these species the sucking instinct is very strong and in some the firstborn may start sucking before the last has arrived.

Table I shows the composition of the milk of the rat and rabbit, and of the cat, dog and fox. All are characterized by their low carbohydrate content and high protein and fat contents. They also have high concentrations of calcium and phosphorus; the corresponding values for $\mathrm{Ca}$ in human milk and cow's milk are about 7.5 and $30 \mathrm{mmol} / \mathrm{l}$ respectively. On a plentiful supply of these milks the young grow very rapidly and double their birth weight in a week or so. Studies on rabbits (Davies, Widdowson \& McCance, 1964) and puppies (McCance \& Widdowson, I $95^{8}$ ) showed that about $90 \%$ of the nitrogen in the food was absorbed and retained for growth. In the rabbits, moreover, almost $100 \%$ of the $\mathrm{Ca}$ and $\mathrm{P}$ in the food was absorbed and retained. Animals that are immature at birth, and babies born prematurely, have a high requirement for Ca because their bones are poorly calcified, and one of the problems about feeding premature babies is how to get sufficient $\mathrm{Ca}$ into them. Premature babies do not absorb fat at all well, particularly cow's milk fat (Tidwell, Holt, Farrow $\&$ Neale, 1935). The lipase activity in the small intestine is low at birth and is lower in premature babies than in those born at full term (Droese \& Stolley, 1960). The secretion of bile acids is also lower in premature babies than in full-term ones, and lower in full-term babies than at the end of the first year. In newborn rats, too, the lipase activity both of the small intestine and of the pancreas is very low indeed (Rokos, Hahn, Koldovský \& Procházká, 1963) and it rises at the time of weaning, when the animal starts to take solid food. This is rather paradoxical since rat milk is rich in fat and the weaning diet, at any rate of the laboratory rat, contains very little (Hahn \& Koldovský, 1967). Rat milk has some lipase activity, but this is not thought to be quantitatively very important (Koldovský, 1969). How then does the immature newborn rat manage to deal with its high-fat diet? The studies of Koldovský ( 1969 ) strongly suggest that in infant rats, particularly newborn rats, triglycerides are absorbed without being hydrolysed, and these triglycerides are then laid down as body fat. Whether this is also true of other newborn animals has not yet been investigated. As far as I know there is no evidence that the premature human baby does not hydrolyse the triglycerides in its food. In fact we think that the poor absorption of $\mathrm{Ca}$ by premature babies, particularly when cow's milk is given, is partly due to unabsorbed long-chain saturated fatty acids combining with $\mathrm{Ca}$ and interfering with its absorption. If immature newborn animals do 
Table 2. Fatty acid composition of milk fats ( $\mathrm{mg} / \mathrm{g}$ total fat) from various species*

\begin{tabular}{|c|c|c|c|c|c|c|c|c|c|c|c|}
\hline \multirow[b]{2}{*}{ Species } & \multicolumn{11}{|c|}{ Fatty acid } \\
\hline & C6:0 & C8:0 & Cro:0 & $\mathrm{C}_{12: 0}$ & $\mathrm{Cr}_{4: 0}$ & Cr6:0 & Cr6:I & CI 8:0 & $\mathrm{C}_{1} 8: \mathrm{I}$ & $C_{18: 2}$ & $\mathrm{C}_{1} 8: 3$ \\
\hline Mouse & 14 & - & 46 & $8 \mathrm{I}$ & II9 & 232 & 39 & 29 & 257 & $\mathrm{r} 6_{3}$ & 20 \\
\hline & $T$ & 25 & 87 & 95 & 119 & 301 & 22 & $3^{\circ}$ & 189 & $\mathrm{II}_{4}$ & 13 \\
\hline Rabbit & $\mathrm{T}$ & 224 & 201 & 29 & I7 & $I_{42}$ & 20 & 38 & 136 & 140 & 44 \\
\hline Dog & - & - & 10 & IO & 40 & 273 & 64 & 44 & 418 & I 26 & 19 \\
\hline Cat & - & - & IO & I9 & 72 & 246 & $5 \mathrm{I}$ & 104 & 374 & 85 & 20 \\
\hline Lion & - & - & 7 & $\mathrm{~T}$ & 43 & 264 & 89 & $2 \mathrm{I}$ & 338 & 109 & 129 \\
\hline Man & I & 4 & 22 & 18 & 38 & 262 & 29 & 81 & 364 & 83 & 4 \\
\hline Cow & 10 & 12 & 26 & 22 & IOS & 263 & $3 I$ & 132 & 322 & I6 & \\
\hline
\end{tabular}

$T$, trace.

"From Macy \& Kelly (196r) and Glass, Troolin \& Jenness (1967).

absorb unaltered triglycerides this would help to explain why they are able to absorb such a high proportion of their $\mathrm{Ca}$.

Table 2 shows the fatty acid composition of the milk of some rodents and carnivores that have very immature young (Glass, Troolin \& Jenness, 1967). Average values for human and cow's milk are given for comparison. The milk of the rat and mouse has more $\mathrm{C}_{10}: 0, \mathrm{C}_{12}: 0$ and $\mathrm{C}_{4}$ :0 fatty acids than the fat of human or cow's milk, whereas the milk of carnivores is rather similar to human milk in fatty acid composition. The fat of rabbit's milk is quite different. It has much higher proportions of the short-chain fatty acids C8:0 and Cro:o than that of any of the other species. These are thought to be synthesized from precursors supplied by the bacteria in the large caecum of this herbivore, and presumably the same explanation would hold for the large amount of capric acid, Cio:0, in elephant milk fat (McCullagh, Lincoln \& Southgate, I969). All these milks have less stearic acid ( $\left.\mathrm{C}_{1} 8: 0\right)$ and more linoleic acid ( $\left.\mathrm{C}_{1} 8: 2\right)$ than cow's milk. Apart from this there is no uniformity in their composition. In non-ruminants the fatty acid composition of the milk fat depends partly on the diet of the lactating animal, whether it be an omnivore, a herbivore or a carnivore, and the immature young of these various orders are evidently adapted to make full use of fats of very different fatty acid composition. How kittens would fare on rabbit's milk, or vice versa, still remains to be investigated.

Dysmaturity, lightness for dates or intrauterine growth retardation, as it is variously called, also presents feeding problems in the human infant. However, because maturation has gone on even though growth in size has been slow, a baby whose growth was retarded before birth is more mature than a well-grown premature baby of similar body-weight. The same is true of animals. Intrauterine growth retardation occurs spontaneously in some species, especially when the litter is a large one. It is due to an unfortunate siting in the uterine horn, where the blood supply is not as good as elsewhere, and has been described in mice (McLaren, I965), rabbits (Rosahn \& Greene, 1936), guinea-pigs (Ibsen, 1928) and pigs (Perry \& Rowell, 1969; Widdowson, 197I). It has also been produced experimentally in rats by ligating the main uterine blood vessels to one horn on the I6th day of pregnancy 
(Wigglesworth, 1964) or by giving the mother a diet inadequate in energy or protein. Such 'runt' animals, when left with the mother and the rest of the litter, are less likely to survive than their larger litter-mates because they are weaker and therefore less able to secure a teat and a supply of food. On the other hand they need food more urgently than their larger litter-mates because they are smaller and therefore lose heat more rapidly, and they do not have the stores of glycogen which their larger littermates possess. But with care they can be reared. All the studies that have been made on their subsequent progress, however, show that even when they have a plentiful supply of food, animals that were small at birth gain weight more slowly than their larger fellows and become smaller adults. They show no sign of the catch-up growth that is characteristic of the older undernourished animal when it is rehabilitated (McCance \& Widdowson, 1974). Why this should be so has not yet been fully explained, but clearly failure to take enough food to enable them to catch up, even when this is available, is at the root of the problem.

Now I will turn to the other side of the picture: the baby that gets too fat because it is overfed. In the first place I want to emphasize that it is physiological for animals and babies to lay down fat during the first weeks or months after birth. Some animals are born with very little fat in their bodies and they deposit white fat in their subcutaneous tissues and round their internal organs during the period while they are living on mother's milk. In the rat the percentage of fat in the body may rise from the newborn value of $1 \%$ to as much as $16 \%$ during the first 2 weeks after birth. The human baby, which develops much farther before birth than the rat, rabbit, kitten or puppy, has already got about $\mathrm{I} 6 \%$ of fat in its body by the time it is born at full term. Even so, all the evidence goes to show that this percentage normally increases up to 6 months or so, but when the child becomes more active the percentage falls a little, although the total amount goes on increasing as the child grows. We are therefore considering an exaggeration of a physiological process. Is there any counterpart for this exaggeration in animals? I am sure it is true to say that obesity is never a problem for animals living in their natural surroundings, just as it is rarely ever a problem for babies living on their natural food, which is breast milk. Young animals can be made fat, however, by being fed on a diet more concentrated in energy than their usual one. I can illustrate this by describing an experiment recently done in our laboratory by Shaw (1973). The first stage was to rear rats from the day after birth in small and large litters, that is three or fifteen to twenty on one mother, as described by Kennedy (I957) and Widdowson \& McCance (I960). Those suckled three to one mother gained weight much faster than those suckled in litters of fifteen to twenty, because each rat was able to get more milk. In this particular experiment the mean body-weights at weaning at 3 weeks were 45 and $26 \mathrm{~g}$ for small and large litters respectively. The heavier animals were bigger in every way: they were longer, had bigger skeletons, and their muscles and organs were bigger. It is true that they also had a higher percentage of fat in their bodies, but they were by no means obese. Half the male rats suckled in small and large litters were then allowed free access to the stock diet and they grew as all other rats previously suckled in this way have grown before them. Those that were small at weaning 
gained weight less rapidly than those that were larger and they became smaller adults. They showed no catch-up growth and therefore behaved like animals whose growth has been retarded in utero.

The other half of the male rats suckled in small and large litters were from weaning at 3 weeks given unlimited amounts of a diet adequate in protein, minerals and vitamins but containing $600 \mathrm{~g}$ lard $/ \mathrm{kg}$, and providing nearly twice as much energy per $\mathrm{kg}$ as the stock diet. For the next 7 weeks the high-fat diet made no difference to the growth rate, and the mean weight at Io weeks was similar to the mean weight of the corresponding animals on the stock diet. Thus, irrespective of the diet after weaning, those originally suckled in small litters weighed $300 \mathrm{~g}$, those suckled in large litters just over $200 \mathrm{~g}$. The diet after weaning, however, did make a difference to the composition of the bodies, and those having the high-fat diet had considerably more fat and less lean body tissue than the animals on the stock diet, although the body-weights were the same.

From ro weeks onwards the weights diverged. Table 3 shows the weights of the four groups of animals at 46 weeks of age. On both stock diet and high-fat diet the rats that were heavier at weaning were still heavier, but the type of diet given from weaning also made a considerable difference, and those having the high-fat diet

Table 3. Mean body-weights $(g)$ of rats reared as small or large litters, and subsequently given a stock or high-fat diet

Treatment during suckling
Weight at weaning ( 3 weeks)
Diet from 3 to 46 weeks
Weight at 46 weeks

Small litters

(High plane)

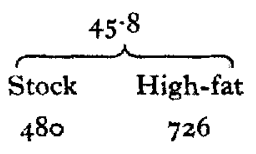

Large litters

(Low plane)

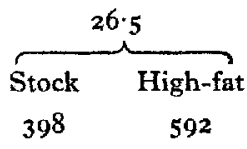

Table 4. Fat in the bodies of rats ( $\mathrm{mg} / \mathrm{g}$ body-wt) reared as large or small litters, and subsequently given a stock or a high-fat diet

Treatment during suckling
Fat content at weaning ( 3 weeks)
Diet from 3 to 46 weeks
Fat content at 46 weeks

Treatment during suckling
Small litters (High plane)

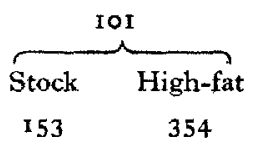

Large litters

(Low plane)

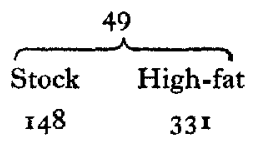

were considerably heavier than the others. They were also very much fatter (Table 4). The plane of nutrition during suckling made virtually no difference to the percentage of fat in the bodies at 46 weeks, though it had made a difference earlier. But the type of diet after weaning made a very big difference indeed, and we know from another of Shaw's experiments that it made a difference too to the number of fat cells in the body, which went on increasing in the obese rats right through the experiment. 
How does this help us over the problems of obesity in young children? They too will take more energy than they require if offered a diet more concentrated than their natural one, and it makes no difference whether they have grown fast or slowly during the first period after birth. Body-weight is no indication of body composition, and one child weighing the same as another of similar age may be very much fatter. If the concentrated diet continues to be offered to rats or children they will continue to eat it in excessive amounts, and it is perhaps worth noting that rats take the high-fat diet much more readily if it is started at 3 weeks of age than if it is first offered later. The final outcome is obvious. We did not try changing the food of the obese rats to the less concentrated stock diet, and hindsight suggests that we should have done. I am sure that the animals would have reduced their energy intake for a time, but I am not prepared to say whether they would have continued to take less energy than before, or whether they would gradually have eaten more and more of the less concentrated diet to bring their energy intake back to its previous high level.

\section{REFERENCES}

Davies, J. S., Widdowson, E. M. \& McCance, R. A. (1964). Br. F. Nutr. 18, $3^{8} 5$.

Droese, W. \& Stolley, H. (1960). Fette Seifen Anstr-Mittel. 62, 281.

Glass, R. L., Troolin, H. A. \& Jenness, R. (I967). Comp. Biochem. Physiol. 22, 415.

Iahn, P. \& Koldovský, O. (1967). Utilization of Nutrients during Postnatal Development. Oxford: Pergamon Press.

Ibsen, H. L. (1928). F. $\exp$. Zool. 5r, 51 .

Kennedy, G. C. (1957). F. Endocr. 16, 9.

Koldovský, O. (1969). Development of the Function of the Small Intestine in Mammals and Man. Basel: S. Karger.

McCance, R. A. \& Widdowson, E. M. (1958). F. Physiol., Lond. 141, 81.

McCance, R. A. \& Widdowson, E. M. (1974). Proc. R. Soc. B. 185, 1,

McCullagh, K. G., Lincoln, H. G. \& Southgate, D. A. T. (1969). Nature, Lond. $222,493$.

McLaren, A. (1965). \%. Reprod. Fert. 9, 79.

Macy, I. G. \& Kelly, H. J. (r96I). In Milk: the Mammary Gland and its Secretion Vol. 2, p. 265 [S. K. Kon and A. T. Cowie, editors]. New York: Academic Press.

Perry, J. S. \& Rowell, J. G. (1969). F. Reprod. Fert. 19, 527.

Rokos, J., Hahn, P., Koldovský, O. \& Procházká, P. (1963). Physiologia bohemoslov. 12, 213.

Rosahn, P. D. \& Greene, H. S. N. (1936). F. exp. Med. 63, gor.

Shaw, W. T. (1973). The effect of early nutrition on deposition of body fat in the rat. PhD Thesis, Cambridge University.

Tidwell, H. C., Holt, L. E., Farrow, H. L. \& Neale, S. (1935). F. Pediat. 6, 48 r.

Widdowson, E. M. (1971). Biologia Neonat, r9, 329 .

Widdowson, E. M. \& McCance, R. A. (1960). Proc. R. Soc. B, ז52, 188.

Wigglesworth, J. S. (I964). F. Path. Bact. 88, 1. 